\title{
Study of FoxP3 ${ }^{+} \mathrm{CD}^{+} \mathrm{CD}^{+} 5^{+}$in systemic lupus erythematosus and rheumatoid arthritis
}

Farag Khalili ${ }^{\mathrm{a}}$, Mohamed Nabil Rafat ${ }^{\mathrm{a}}$, Abdelwahab Lotfya, Mahmoud H. Hemida ${ }^{\mathrm{a}}$, Marwan Sayed ${ }^{\mathrm{a}}$, Mamdouh Attia ${ }^{\mathrm{b}}$

Departments of anternal Medicine, ${ }^{b}$ Clinical Pathology, Al Azhar University, Cairo, Egypt

Correspondence to Farag Khalil, BSc, MSc, MD, Alhusein University Hospital, Internal Medicine Department 7th Floor Cairo, 11311, Egypt. Tel: 01067775783;

e-mail: dr.farag7070@azhar.edu.eg

Received 18 June 2018

Accepted 10 July 2018

The Egyptian Journal of Internal Medicine 2018, 30:289-299

\section{Background}

Systemic lupus erythematosus (SLE) and rheumatoid arthritis (RA) as autoimmune diseases arise owing to failure of immunological self-tolerance. One of the mechanisms employed to control these potentially damaging cells are regulatory $T$ cells (Tregs). The importance of Tregs is underscored by the overwhelming inflammation and autoimmunity that result from their absence. Forkhead box p3 (FoxP3) is an important regulator of Treg function, and the expression of FoxP3 correlates with the expression of other Treg-associated markers such as CD25 and CTLA-4.

Aim

To investigate the frequency of FoxP $3^{+} \mathrm{CD} 4^{+} \mathrm{CD} 25^{\text {thigh }}$ cells (Tregs) in peripheral blood from patients with SLE and those with RA.

Patients and methods

A total of 25 patients with SLE (15 patients with active SLE and 10 patients with inactive SLE), 25 patients with RA (15 patients with active RA and 10 patients with inactive RA), and 10 age-matched and sex-matched healthy controls were enrolled in the study. Patients underwent clinical and laboratory assessment. The frequency of Tregs was determined by flow cytometry.

\section{Results}

The distribution of $\mathrm{FoxP}^{+} \mathrm{CD}^{+} \mathrm{CD}^{+5^{\text {high }}}$ cells (Tregs) revealed a highly significant decrease in the frequency of Treg in patients with SLE compared with healthy controls. Moreover, patients with active SLE showed significantly lower Tregs percent when compared with inactive group.

Moreover, the distribution of FoxP3 ${ }^{+} \mathrm{CD}^{+} \mathrm{CD} 25^{\text {+high }}$ cells (Tregs) revealed a high significantly decrease in the frequency of Treg in patients with RA compared with healthy controls.

Conclusion

$\mathrm{CD}^{+}{ }^{+} \mathrm{CD} 25^{+}$FoxP3 Tregs (as a percent of total CD4 cells) were significantly lower in patients with SLE and those with RA when compared with healthy controls.

\section{Keywords:}

forkhead box P3, rheumatoid arthritis, systemic lupus erythematosus, regulatory $\mathrm{T}$ cells

Egypt J Intern Med 30:289-299

(c) 2019 The Egyptian Journal of Internal Medicine

1110-7782

\section{Introduction}

Systemic lupus erythematosus (SLE) is an autoimmune disease characterized by autoantibody production. The pathogenesis of SLE is not completely understood, with various types of immune cells being involved [1].

Rheumatoid arthritis (RA) is a common systemic autoimmune disease with chronic relapsing inflammation, primarily in peripheral joints. It is characterized by disturbed immune regulation, which induces a progressive cartilage and bone destruction [2,3].

Natural regulatory T cells (Tregs) are $\mathrm{CD} 4^{+} \mathrm{CD} 25^{+} \mathrm{T}$ cells generated in the thymus in early years of life with the ability to bind self-antigens by their T-cell receptor. They are distinguished from adaptive Treg that are induced in the peripheral blood by conversion of $\mathrm{CD} 4^{+}$
$\mathrm{CD} 25^{-}$naive $\mathrm{T}$ cells in the presence of a particular microenvironment [4].

The importance of Treg in the development of autoimmune diseases was recognized by Sakaguchi and colleagues who were the first to show that transfer of $\mathrm{CD} 4^{+} \mathrm{T}$ cells depleted of $\mathrm{CD} 25^{+} \mathrm{T}$ cells, by specific monoclonal antibodies against $\mathrm{CD} 25$, into $\mathrm{BALB} / \mathrm{c}$ athymic nude mice caused spontaneous development of T-cell-dependent autoimmune diseases (such as thyroiditis, gastritis, insulitis, sialadenitis, adrenalitis, oophoritis, glomerulonephritis, and polyarthritis).

\footnotetext{
This is an open access journal, and articles are distributed under the terms of the Creative Commons Attribution-NonCommercial-ShareAlike 4.0 License, which allows others to remix, tweak, and build upon the work non-commercially, as long as appropriate credit is given and the new creations are licensed under the identical terms.
} 
When these mice were reconstituted by $\mathrm{CD} 4^{+} \mathrm{CD} 25^{+} \mathrm{T}$ cells within a limited period after $\mathrm{CD} 4^{+} \mathrm{CD} 25^{-} \mathrm{T}$-cell transfer, the autoimmune disease development was successfully prevented [5].

The discovery of the forkhead winged-helix transcription factor forkhead box $\mathrm{P} 3$ (FoxP3) as master regulator for Treg added a key marker for this T-cell subset. FoxP3, in fact, is constitutively expressed at high levels in both natural and adaptive $\mathrm{CD} 4^{+} \mathrm{CD} 25^{\text {high }}$ Treg in human beings and mice. It is required for the natural Treg lineage commitment in the thymus and is essential in stabilizing and amplifying a Treg program, inclusive of anergy and defective interleukin 2 (IL-2) production, induced by interaction between Treg precursors and stromal cells in the thymus [6].

Furthermore, it has been shown that persistence of expression of FoxP3 is important for maintaining suppressor function. Interestingly, it is now well accepted that FoxP3, despite being a distinctive marker for Treg, can also be expressed by human effector $T$ cells after activation. However, its expression on these cells is transient and never reaches the expression levels displayed by Treg [7].

Although the concept of the preventive role of Treg in autoimmunity is widely accepted, data regarding SLE and RA are inconsistent. The studies on circulating Treg characterized phenotypically indicate either a decrease or increase or no change in their number compared with healthy controls. These discrepancies throughout the literature may be owing to the heterogeneity of the disease, studies in patients with different levels of disease activity, the possible effect of immunosuppressive treatment, and other factors $[8,9]$.

The aim of the present study was to investigate the frequency of FoxP3 ${ }^{+} \mathrm{CD} 4^{+} \mathrm{CD} 25^{\text {thigh }}$ cells (Tregs) in peripheral blood from patients with SLE and RA.

\section{Patients and methods}

\section{Type of the study}

A cross-sectional observational study was conducted.

\section{Site and time of the study}

The study was conducted at the Internal Medicine Department, Faculty of Medicine, Al Azhar University, during the period from December 2016 to December 2017.

\section{Patients}

The study was conducted on 60 patients: 25 patients with SLE, where 22 patients were females and three were males; 25 patients with RA, where 20 patients were females and five were males; and 10 age-matched and sex-matched apparently healthy participants (male/female $=2 / 8)$, who served as controls.

The patients were divided into three groups:

Group I: 25 patients with SLE, and they were divided according to SLE activity into two subgroups:

Group IA: 15 patients with active SLE [Systemic Lupus Erythematosus Disease Activity Index (SLEDAI) >6].

Group IB: 10 patients with inactive SLE (SLEDAI $\leq 6)$.

Group II: 25 patients with RA, and they were divided according to RA activity into two subgroups:

Group IIA: 15 patients with active RA (DAS-28 $\geq 3$ ). Group IIB: 10 patients with inactive RA (DAS$28<3.2)$.

Group III: 10 age-matched and sex-matched apparently healthy participants (male/female=2/8).

\section{Ethical considerations}

(1) Before data collection, approval was granted by the ethical committee of Al Azhar Faculty of Medicine.

(2) Informed consent was obtained from every patient to participate in this study.

(3) Proper treatment for diseased cases was prescribed.

Patients with SLE were diagnosed according to SLE International Collaborating Clinics/American College of Rheumatology 2012 Criteria [10]. Patients with RA were diagnosed on the basis American College of Rheumatology /EULAR (2010) classification criteria for RA [11].

Any patient having coronary heart disease, diabetes, or end-stage renal disease, pregnant patients, patients on treatment by immunosuppressive drugs at the time of enrollment, and patient on treatment by high-dose glucocorticoids more than $20 \mathrm{mg} /$ day at the time of enrollment were excluded from the study.

\section{Methods}

All participants were subjected to the following:

(1) Detailed history taking.

(2) Full clinical examination.

(3) Routine laboratory investigations, including erythrocyte sedimentation rate (ESR), C-reactive 
protein (CRP), fasting and 2-h postprandial blood glucose, complete blood count, complete urine analysis, and liver and kidney function tests.

(4) Measurement of proteins in $24 \mathrm{~h}$ urine $(\mathrm{g} / 24 \mathrm{~h})$.

(5) Antinuclear antibodies and anti-double stranded DNA antibodies (anti-dsDNA measurement was done by immunofluorescence technique, where titer of $1 / 40$ or more is considered positive (done for patients with SLE only)).

(6) Serum complement level (C3 and C4) measurement was done by nephelometry (normal level of C3 is $84-160 \mathrm{mg} / \mathrm{dl}$ and for C4 $12-36 \mathrm{mg} / \mathrm{dl}$ ) (done for patients with SLE only).

(7) Rheumatoid factor measurement was done by turbidimetry. Normal level is $0-1 \mathrm{IU} / \mathrm{ml}$ (done for patients with RA only).

(8) Anti-cyclic citrullinated peptide measurement was done by chemiluminescence. Normal level is $0-5 \mathrm{U} / \mathrm{ml}$ (done for patients with RA only).

(9) The detection of percent of $\mathrm{FoxP}^{+} \mathrm{CD}^{+}$ $\mathrm{CD} 25^{\text {high }}$ Treg was carried out by direct immunofluorescence technique using $\mathrm{BD}$ FACSC into flow cytometer using BD FACSD via 8.02 system (Becton Dickinson Company, Town, USA), which was performed on the peripheral blood of both patients and controls.

(a) Two tubes each containing $50 \mu \mathrm{l}$ of whole anticoagulated blood were set for each patient, one for the tested monoclonal antibodies and the other for isotype controls. Samples in each tube were lysed using $1-\mathrm{ml}$ lysing solution and washed with PBS. Cell counts were adjusted at $5-10 \times 10^{3} / \mu 1$.

(b) The cells were stained with combinations of the following antibodies $(5 \mu \mathrm{l})$ of anti-CD25PE, anti-CD4-FITC cocktail (first tube) and $\mathrm{PE}$ isotype control (second tube).

(c) Tubes were then incubated in dark for $20 \mathrm{~min}$ followed by washing with PBS.

(d) The cell pellets were resuspended in $0.5 \mathrm{ml}$ of freshly prepared fixation/permeabilization working solution and incubated for $30 \mathrm{~min}$ at $4^{\circ} \mathrm{C}$ in dark

(e) This was followed by washing once with PBS and then washing once again with $1 \mathrm{ml}$ of $1 \times$ permeabilization buffer.

(f) Ten microliters of PE-Cy5 FoxP3 or PE-Cy5 isotype control was added to respective tubes and incubated for $30 \mathrm{~min}$ at $4^{\circ} \mathrm{C}$ in dark.

(g) This was followed by washing once with PBS and then resuspension in PBS for analysis.

(h) Data acquisition and analysis were performed on BD FACSCanto flow cytometer using BD FACSDiva 8.02 system. (i) Lymphocytes were gated via their forward and side scatter properties, and then $\mathrm{CD} 4^{+}$ cells were identified based on their expression of CD4 versus side scatter properties.

(j) The gated $\mathrm{CD}^{+} \mathrm{T}$ cells were then assessed for both CD25 expressions, where $\mathrm{CD}^{+}$ $\mathrm{CD} 25^{\text {high }} \mathrm{T}$ cells were discriminated from $\mathrm{CD} 4^{+} \mathrm{CD} 25^{\mathrm{dim}} \mathrm{T}$ cells.

(k) Finally, CD $4^{+} \mathrm{CD} 25^{\text {high }} \mathrm{T}$ cells were assessed for FoxP3 expression (Fig. 1). Treg were expressed as a percent of $\mathrm{CD} 4^{+} \mathrm{T}$ cells.

\section{Statistical analysis}

The data obtained from the history, clinical examination, and investigations were tabulated and statistically analyzed with the aid of computer's GraphPad Prism program, version 7 [12]. Data were statistically described in terms of mean $\pm \mathrm{SD}$, when appropriate. Spearman's test was used for correlation analysis. Student's $t$ test was used for comparison of numerical variables between the study groups. $P$ values less than 0.05 were considered statistically significant at the level of $95 \%$.

\section{Results}

Frequencies of regulatory $T$ cells

The distribution of FoxP $3^{+} \mathrm{CD} 4^{+} \mathrm{CD} 25^{\text {thigh }}$ cells (Tregs) revealed a highly significant decrease in the frequency of Treg in patients with SLE compared with healthy controls $(1.08 \pm 0.29$ and $2.46 \pm 0.7$ for active SLE and control, respectively, $P<0.0001) \quad(1.54 \pm 0.23$ and $2.46 \pm 0.7$ for inactive SLE and control, respectively, $P=0.0003$ ) (Tables 1-4).

Moreover, patients with active SLE showed significantly lower Tregs percent when compared with inactive group $(1.08 \pm 0.29$ vs. $1.54 \pm 0.23$, $P=0.0004)$ (Table 5 and Fig. 2).

The distribution of $\mathrm{FoxP}^{+} \mathrm{CD} 4^{+} \mathrm{CD} 25^{\text {thigh }}$ cells (Tregs) revealed a highly significant decrease in the frequency of Treg in patients with RA compared with healthy controls $(1.01 \pm 0.31$ and $2.46 \pm 0.7$ for active RA and control, respectively, $P<0.0001)(1.52 \pm 0.24$ and $2.46 \pm 0.7$ for inactive RA and control, respectively, $P=0.0003)$.

Moreover, patients with active RA showed significantly lower Tregs percent when compared with the inactive group $(1.01 \pm 0.31$ vs. $1.52 \pm 0.24$, $P=0.0002$ ) (Table 5 and Fig. 2). 
Figure 1

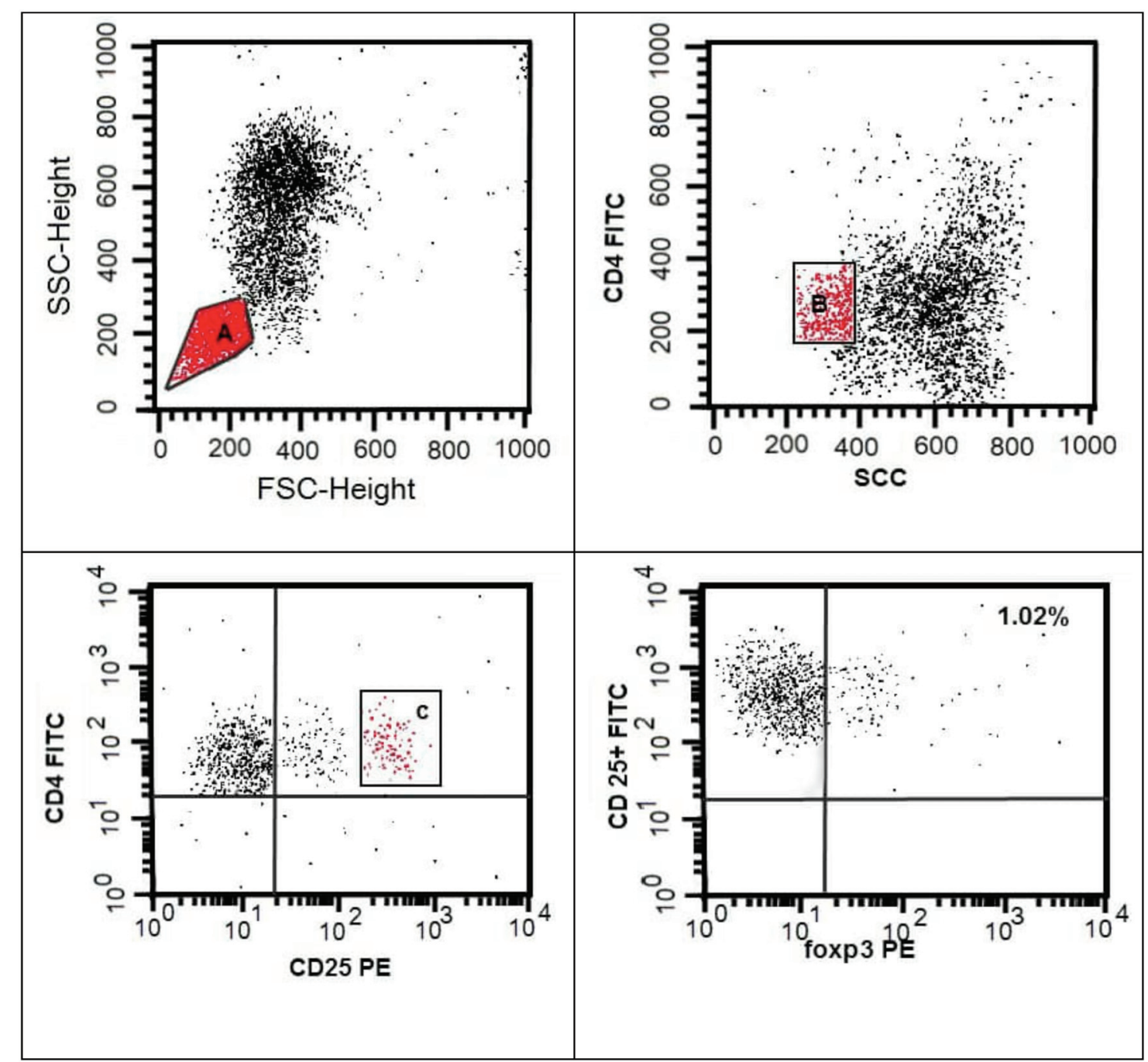

Show the stages of lymphocytes a: T- L ymphocyte,b: CD4+, c: CD25+, d: Foxp3.

Table 1 Comparison between clinical variables in patients with systemic lupus erythematosus and control groups

\begin{tabular}{|c|c|c|c|c|c|c|}
\hline \multirow[t]{2}{*}{ Variables } & \multirow{2}{*}{$\begin{array}{c}\text { Group IA (active } \\
\text { SLE) }\end{array}$} & \multirow{2}{*}{$\begin{array}{c}\text { Group IB } \\
\text { (inactive SLE) }\end{array}$} & \multirow{2}{*}{$\begin{array}{l}\text { Group III } \\
\text { (control) }\end{array}$} & \multicolumn{3}{|c|}{$P$ value } \\
\hline & & & & $\begin{array}{l}\text { Group IA and } \\
\text { group III }\end{array}$ & $\begin{array}{l}\text { Group IB and } \\
\text { group III }\end{array}$ & $\begin{array}{c}\text { Group IA and } \\
\text { group IB }\end{array}$ \\
\hline Age (years) & $33 \pm 8.6$ & $32.6 \pm 5.15$ & $32 \pm 6.61$ & 0.6023 & 0.8235 & 0.8574 \\
\hline Age of onset (years) & $28.27 \pm 7.6$ & $25.3 \pm 8.68$ & & & & 0.3758 \\
\hline Disease duration (years) & $6.4 \pm 3.69$ & $6.3 \pm 4.21$ & & & & 0.5784 \\
\hline Weight (kg) & $68.13 \pm 9.64$ & $68.5 \pm 9.51$ & $69.9 \pm 4.95$ & 0.5999 & 0.6847 & 0.9262 \\
\hline Height (cm) & $171 \pm 8.18$ & $169.1 \pm 6.5$ & $172.3 \pm 5.7$ & 0.6681 & 0.2592 & 0.5449 \\
\hline BMI $\left(\mathrm{kg} / \mathrm{m}^{2}\right)$ & $23.5 \pm 3.2$ & $24 \pm 3.42$ & $23.58 \pm 1.99$ & 0.9448 & 0.7412 & 0.7134 \\
\hline $\begin{array}{l}\text { Systolic blood pressure } \\
(\mathrm{mmHg})\end{array}$ & $149.7 \pm 23.03$ & $125.5 \pm 16.06$ & $120.5 \pm 6.85$ & $0.0008^{\star * \star}$ & 0.3772 & $0.0085^{\star *}$ \\
\hline $\begin{array}{l}\text { Diastolic blood pressure } \\
(\mathrm{mmHg})\end{array}$ & $94.67 \pm 15.06$ & $78.5 \pm 13.13$ & $76.5 \pm 7.09$ & $0.0017^{\star \star}$ & 0.6768 & $0.0111^{*}$ \\
\hline SLEDAI & $16.3 \pm 5.4$ & $1.6 \pm 0.48$ & & & & $<0.0001^{\star \star \star \star}$ \\
\hline
\end{tabular}

SLEDAI, systemic lupus erythematosus disease activity index. Data are presented as mean \pm SD. SLE, systemic lupus erythematosus. *, ${ }^{* *},{ }^{* * *},{ }^{* * *}$ Denote the degree of significance low to high and very high significance.

Correlations between Treg (percent) and parameters of lupus activity

In the present study, positive correlations were observed between Treg (percent) and C3 ( $r=0.5714$ and $P=0.0028)$ and $\mathrm{C} 4(r=0.2870$ and $P=0.0185)$ in patients with SLE, whereas negative correlations were observed between Treg (percent) and ESR ( $r=-0.4933$ and $P=0.0122), 24-h$ urinary protein $(r=-0.4981$ and 
Table 2 Comparison between laboratory variables in patients with systemic lupus erythematosus and control groups

\begin{tabular}{|c|c|c|c|c|c|c|}
\hline \multirow[t]{2}{*}{ Variables } & \multirow{2}{*}{$\begin{array}{c}\text { Group IA (active } \\
\text { SLE) }\end{array}$} & \multirow{2}{*}{$\begin{array}{c}\text { Group IB } \\
\text { (inactive SLE) }\end{array}$} & \multirow{2}{*}{$\begin{array}{l}\text { Group III } \\
\text { (control) }\end{array}$} & \multicolumn{3}{|c|}{$P$ value } \\
\hline & & & & $\begin{array}{l}\text { Group IA and } \\
\text { group III }\end{array}$ & $\begin{array}{l}\text { Group IB and } \\
\text { group III }\end{array}$ & $\begin{array}{l}\text { Group IA and } \\
\text { group IB }\end{array}$ \\
\hline Hemoglobin (g/dl) & $9.99 \pm 1.39$ & $12.50 \pm 0.99$ & $13.43 \pm 0.72$ & $<0.0001^{\star \star \star \star}$ & $0.0301^{*}$ & $<0.0001^{\star \star \star *}$ \\
\hline WBC $(\times 1000 / \mathrm{ml})$ & $8.02 \pm 3.34$ & $7.36 \pm 1.96$ & $6.9 \pm 1.5$ & 0.3347 & 0.5722 & 0.5772 \\
\hline Platelets $(\times 1000 / \mathrm{ml})$ & $182.7 \pm 93.35$ & $200.6 \pm 104.3$ & $289 \pm 88.66$ & $0.0053^{\star \star}$ & $0.0381^{*}$ & 0.6575 \\
\hline $\operatorname{ESR}(\mathrm{mm} / \mathrm{h})$ & $87.93 \pm 27.27$ & $48.6 \pm 19.59$ & $8 \pm 1.6$ & $<0.0001^{\star \star \star \star}$ & $<0.0001^{\star \star \star \star}$ & $0.0007^{\star * *}$ \\
\hline ALT (IU/ml) & $21.8 \pm 8.2$ & $27 \pm 10.11$ & $18.7 \pm 7.68$ & 0.3531 & 0.0535 & 0.1705 \\
\hline AST (IU/ml) & $23.8 \pm 8.6$ & $26.7 \pm 7.6$ & $20 \pm 7.7$ & 0.2652 & 0.0676 & 0.4095 \\
\hline Serum creatinine $(\mathrm{mg} / \mathrm{dl})$ & $1.16 \pm 0.32$ & $1 \pm 0.17$ & $0.85 \pm 0.13$ & $0.0100^{* *}$ & $0.0469^{\star}$ & 0.1741 \\
\hline BUN & $27.3 \pm 7.6$ & $19.9 \pm 4.9$ & $14.5 \pm 1.78$ & $<0.0001^{\star \star \star \star}$ & $0.0045^{\star \star}$ & $0.0125^{\star}$ \\
\hline eGFR & $84.8 \pm 27.9$ & $99.6 \pm 14.3$ & $115.2 \pm 19.1$ & $0.0064^{\star \star}$ & 0.0538 & 0.1375 \\
\hline Serum albumin $(g / d l)$ & $2.65 \pm 0.43$ & $3.51 \pm 0.54$ & $4.39 \pm 0.44$ & $<0.0001^{\star \star \star \star}$ & $0.0008^{\star \star \star}$ & $0.0028^{\star *}$ \\
\hline $24 \mathrm{~h}$ urinary proteins $(\mathrm{g})$ & $2.85 \pm 2.16$ & $0.186 \pm 0.08$ & $0.045 \pm 0.022$ & $0.0005^{\star \star \star}$ & $<0.0001^{\star \star \star \star}$ & $0.0008^{\star \star \star}$ \\
\hline C3 (mg/dl) & $51.67 \pm 33.61$ & $86.2 \pm 21.96$ & $115.9 \pm 26.09$ & $<0.0001^{\star \star \star \star}$ & $0.0131^{*}$ & $0.0089^{\star \star}$ \\
\hline $\mathrm{C} 4(\mathrm{mg} / \mathrm{dl})$ & $14.8 \pm 8.5$ & $23.2 \pm 9.7$ & $34.4 \pm 10.27$ & $<0.0001^{\star \star \star \star}$ & $0.0224^{\star}$ & $0.0323^{\star}$ \\
\hline $\begin{array}{l}\text { Anti-double stranded DNA } \\
\text { antibody }\end{array}$ & $118.7 \pm 67.31$ & $44.3 \pm 25.31$ & $11.8 \pm 4.59$ & $<0.0001^{\star \star \star \star}$ & $0.0008^{\star \star * *}$ & $0.0030^{* *}$ \\
\hline
\end{tabular}

Data are presented as mean \pm SD. ALT, alanine aminotransferase; AST, aspartate aminotransferase; BUN, blood urea nitrogen; eGFR, estimated glomerular filtration rate; ESR, erythrocyte sedimentation rate; SLE, systemic lupus erythematosus; WBC, white blood cell. *, **, ${ }^{* * *},{ }^{* * *}$ Denote the degree of significance low to high and very high significance

Table 3 Comparison between clinical variables in patients with rheumatoid arthritis and control groups

\begin{tabular}{|c|c|c|c|c|c|c|}
\hline \multirow[t]{2}{*}{ Variables } & \multirow{2}{*}{$\begin{array}{c}\text { Group IIA } \\
\text { (active RA) }\end{array}$} & \multirow{2}{*}{$\begin{array}{c}\text { Group IIB } \\
\text { (inactive RA) }\end{array}$} & \multirow{2}{*}{$\begin{array}{l}\text { Group III } \\
\text { (control) }\end{array}$} & \multicolumn{3}{|c|}{$P$ value } \\
\hline & & & & $\begin{array}{l}\text { Group IIA and } \\
\text { group III }\end{array}$ & $\begin{array}{l}\text { Group IIB and } \\
\text { group III }\end{array}$ & $\begin{array}{l}\text { Group IIA and } \\
\text { group IIB }\end{array}$ \\
\hline Age (years) & $37 \pm 8.03$ & $36.1 \pm 6.35$ & $32 \pm 6.61$ & 0.2135 & 0.1010 & 0.9163 \\
\hline Age of onset (years) & $30.4 \pm 7.99$ & $30 \pm 7.74$ & & & & 0.9024 \\
\hline Disease duration (years) & $6.6 \pm 6.97$ & $6.2 \pm 4.1$ & & & & 0.8721 \\
\hline Weight $(\mathrm{kg})$ & $68.47 \pm 6.05$ & $66.6 \pm 5.44$ & $69.9 \pm 4.95$ & 0.5406 & 0.1732 & 0.4404 \\
\hline Height $(\mathrm{cm})$ & $172.6 \pm 5.38$ & $173.7 \pm 5.22$ & $172.3 \pm 5.7$ & 0.8955 & 0.5762 & 0.6175 \\
\hline BMI $\left(\mathrm{kg} / \mathrm{m}^{2}\right)$ & $23.08 \pm 3.04$ & $22.15 \pm 2.36$ & $23.58 \pm 1.99$ & 0.6525 & 0.1607 & 0.4239 \\
\hline $\begin{array}{l}\text { Systolic blood pressure } \\
(\mathrm{mmHg})\end{array}$ & $129.3 \pm 12.37$ & $128 \pm 10.59$ & $120.5 \pm 6.85$ & 0.0521 & 0.0764 & 0.7828 \\
\hline $\begin{array}{l}\text { Diastolic blood pressure } \\
(\mathrm{mmHg})\end{array}$ & $82.67 \pm 7.9$ & $81 \pm 6.9$ & $76.5 \pm 7.09$ & 0.0604 & 0.1701 & 0.5970 \\
\hline DAS-28 score & $5.197 \pm 1.19$ & $0.8 \pm 0.25$ & & & & $<0.0001^{\star \star \star}$ \\
\hline
\end{tabular}

Data are presented as mean \pm SD. RA, rheumatoid arthritis. ${ }^{\star \star \star \star}$ Denote the degree of significance low to high and very high significance.

$P=0.0113)$, anti-dsDNA antibodies $(r=-0.4325$ and $P=0.0308)$, and SLEDAI $(r=-0.5702$ and $P=0.0029)$ (Figs 3-9).

\section{Correlations between Treg (percent) and parameters of} rheumatoid arthritis activity

In the current study, negative correlations were observed between Treg (percent) and ESR $(r=-0.6018$ and $P=0.0015), \mathrm{CRP}(r=-0.5931$ and $P=0.0018)$, and DAS-28 score $(r=-0.6825$ and $P=0.0002)$ in patients with RA.

\section{Discussion}

The human immune system is equipped with different mechanisms involved in maintaining immune tolerance and protection against autoimmunity. Treg lymphocytes are the key cells controlling the autoimmunization process. Their role is illustrated by an active and dominant control over the function of effector T cells [13].

SLE is a chronic autoimmune disease that can be fatal. As occurs in other autoimmune diseases, the immune system attacks the body's cells and tissues, resulting in inflammation and tissue damage [14]. It is associated with abnormal immune response including production of autoantibodies; abnormalities of the complement system, T cell-B cell interaction, phagocytosis, and Tcell hyperactivity represent a central feature of SLE [15]. 
Table 4 Comparison between laboratory variables in patients with rheumatoid arthritis and control groups

\begin{tabular}{|c|c|c|c|c|c|c|}
\hline \multirow[t]{2}{*}{ Variables } & \multirow{2}{*}{$\begin{array}{l}\text { Group IIA } \\
\text { (active RA) }\end{array}$} & \multirow{2}{*}{$\begin{array}{c}\text { Group IIB } \\
\text { (inactive RA) }\end{array}$} & \multirow{2}{*}{$\begin{array}{l}\text { Group III } \\
\text { (control) }\end{array}$} & \multicolumn{3}{|c|}{$P$ value } \\
\hline & & & & $\begin{array}{l}\text { Group IIA and } \\
\text { group III }\end{array}$ & $\begin{array}{l}\text { Group IIB and } \\
\text { group III }\end{array}$ & $\begin{array}{c}\text { Group IIA and } \\
\text { group IIB }\end{array}$ \\
\hline Hemoglobin (g/dl) & $11.27 \pm 1.42$ & $12.8 \pm 0.87$ & $13.43 \pm 0.72$ & $0.0002^{\star \star *}$ & 0.0974 & 0.0062 \\
\hline WBC $(\times 1000 / m l)$ & $5.93 \pm 1.68$ & $6.42 \pm 2.32$ & $6.9 \pm 1.5$ & 0.1517 & 0.5827 & 0.5491 \\
\hline Platelets $(\times 1000 / \mathrm{ml})$ & $234.5 \pm 85.3$ & $229.4 \pm 66.6$ & $289 \pm 88.6$ & 0.1057 & 0.0645 & 0.8742 \\
\hline $\operatorname{ESR}(\mathrm{mm} / \mathrm{h})$ & $84.27 \pm 22.8$ & $26 \pm 9.9$ & $8 \pm 1.6$ & $<0.0001^{\star \star \star \star}$ & $<0.0001^{\star \star \star \star}$ & $<0.0001^{\star \star \star \star}$ \\
\hline CRP & $21.9 \pm 6.85$ & $8 \pm 6.49$ & $0.8 \pm 0.4$ & $<0.0001^{* * \star *}$ & $0.0026^{\star *}$ & $<0.0001^{* * * *}$ \\
\hline ALT (IU/ml) & $27.1 \pm 13.8$ & $23.5 \pm 8.39$ & $18.7 \pm 7.68$ & 0.0935 & 0.1991 & 0.4656 \\
\hline AST (IU/ml) & $25.13 \pm 11.4$ & $22.5 \pm 7.6$ & $20 \pm 7.7$ & 0.2275 & 0.4758 & 0.5294 \\
\hline $\begin{array}{l}\text { Serum creatinine } \\
(\mathrm{mg} / \mathrm{dl})\end{array}$ & $1.12 \pm 0.3$ & $0.9 \pm 0.21$ & $0.85 \pm 0.13$ & $0.0160^{\star}$ & 0.3590 & 0.0950 \\
\hline BUN & $21.9 \pm 10.1$ & $20.3 \pm 7.3$ & $14.5 \pm 1.78$ & $0.0315^{\star}$ & $0.0265^{\star}$ & 0.6651 \\
\hline $\begin{array}{l}\text { Rheumatoid factor } \\
\text { positivity }\end{array}$ & $11 / 15(73.3)$ & 7/10 (70) & & & & NS \\
\hline ACCP positivity & $12 / 15(80)$ & 7/10 (70) & & & & NS \\
\hline
\end{tabular}

Data are presented as mean \pm SD and $n / N(\%)$. ACCP, anti-cyclic citrullinated peptide; ALT, alanine aminotransferase; AST, aspartate aminotransferase; BUN, blood urea nitrogen; CRP, C-reactive protein; ESR, erythrocyte sedimentation rate; RA, rheumatoid arthritis; WBC, white blood cell. ${ }^{*},{ }^{* \star},{ }^{* \star *},{ }^{* \star \star *}$ Denote the degree of significance low to high and very high significance.

Table 5 Treg percentage in the studied groups

\begin{tabular}{|c|c|c|c|c|c|}
\hline Variables & $\begin{array}{c}\text { Group IA (active SLE) } \\
(N=15)\end{array}$ & $\begin{array}{l}\text { Group IB (inactive } \\
\text { SLE) }(N=10)\end{array}$ & $\begin{array}{c}\text { Group IIA (active RA) } \\
(N=15)\end{array}$ & $\begin{array}{c}\text { Group IIB (inactive } \\
\text { RA) }(N=10)\end{array}$ & $\begin{array}{l}\text { Group III (control) } \\
\qquad(N=10)\end{array}$ \\
\hline \multicolumn{6}{|l|}{ Treg (\%) } \\
\hline Mean $\pm S D$ & $1.08 \pm 0.29$ & $1.54 \pm 0.23$ & $1.01 \pm 0.31$ & $1.52 \pm 0.24$ & $2.46 \pm 0.6$ \\
\hline Range & $0.66-1.62$ & $1.16-1.92$ & $0.63-1.72$ & $1.17-1.88$ & $1.8-3.66$ \\
\hline \multicolumn{6}{|l|}{$P$ value } \\
\hline $\begin{array}{l}\text { Group IA and } \\
\text { group III }\end{array}$ & $\begin{array}{c}\text { Group IB and group } \\
\text { III }\end{array}$ & Group IIA and group III & $\begin{array}{l}\text { Group IIB and roup } \\
\text { III }\end{array}$ & Group IA and group IB & $\begin{array}{l}\text { Group IIA and } \\
\text { group IIB }\end{array}$ \\
\hline$<0.0001^{* * * *}$ & $0.0003^{\star * \star *}$ & $<0.0001^{* * * *}$ & $0.0003^{\star * \star *}$ & $0.0004^{\star * * *}$ & $0.0002^{\star \star \star *}$ \\
\hline
\end{tabular}

RA, rheumatoid arthritis; SLE, systemic lupus erythematosus. ${ }^{\star \star \star \star}$ Denote the degree of significance low to high and very high significance.

There is a connection between lupus and the disturbance of Tregs that plays an important role in maintaining a healthy immune system. Several studies have demonstrated that decreased numbers and/or function of Tregs contribute to the pathogenesis of SLE [16].

$\mathrm{RA}$ is a chronic inflammatory autoimmune disease arising from a breakdown in self-tolerance, which leads to aberrant immune responses to autoantigens. Tregs constitute one of the key mechanisms of selftolerance and are a major focus of study in RA to design new and improved therapies to reinstate self-tolerance [17].

In this study, we investigated the percent of $\mathrm{CD}^{+}$ $\mathrm{CD} 25^{+}$FoxP3 Tregs in patients with SLE and patients with RA, as well as the correlation with other parameters of disease activity.

The present study included 50 patients divided into group IA (15 patients with active SLE), group IB (10 patients with inactive SLE), group IIA (15 patients with active RA), and group IIB (10 patients with inactive $\mathrm{RA}$ ). $\mathrm{CD}^{+} \mathrm{CD}^{+} 5^{+}$FoxP3 Tregs were estimated for all patients, and their results were compared with those of 10 controls (group III).

In the present cross-sectional, observational study on patients with SLE and patients with RA, results revealed that the level of $\mathrm{CD} 4{ }^{+} \mathrm{CD} 25^{+}$FoxP3 Tregs (as a percent of total CD4 cells) was significantly lower in patients with SLE and patients with RA when compared with healthy controls. Moreover, patients with active SLE and RA showed significant difference when compared with inactive groups.

In the present study, there was a significant correlation between Treg percent and C3, C4 levels, ESR, and SLEDAI in patients with SLE, and a significant correlation between Treg percent and ESR, CRP, and DAS-28 in patients with RA.

Our results of decreased Treg in patients with SLE when compared with healthy controls are in agreement with many other studies [18-23], which investigated 
Figure 2

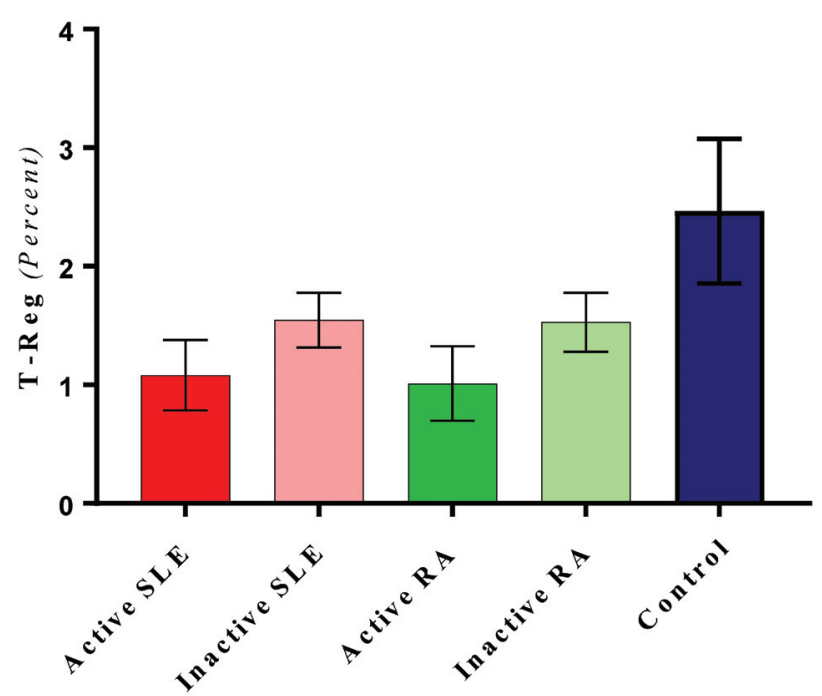

Show that significant deletion of T- Reg. percentage in patients with SLE \& RA in comparison to control group.

Figure 4

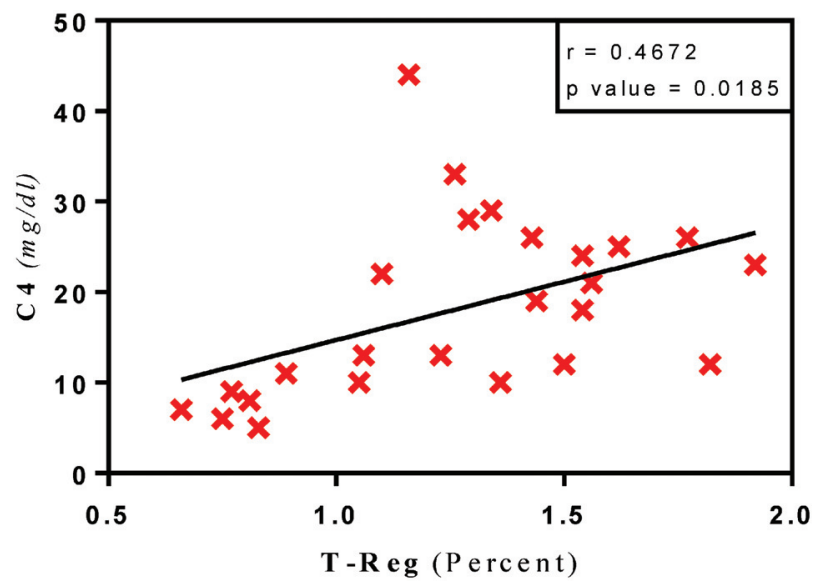

Show Positive correlations were observed between T-Reg (Percent) and $\mathrm{C} 4(r=0.4672 \& \mathrm{P}=0.0185)$

the frequencies of circulating Treg in SLE and found a significant decrease in circulating Treg in peripheral blood of diseased patients when compared with controls.

In accordance to these results, Szmyrka-Kaczmarek et al. [24] found that the proportion of peripheral blood Treg cells in SLE group was significantly lower than that in healthy control group.

The finding of reduced level of Tregs in SLE was explained by many studies on the role of Treg in autoimmune diseases especially in SLE, which showed that the pathogenesis of SLE involves breakdown of immunologic self-tolerance resulting in the development of autoantibodies. Many T-cell
Figure 3

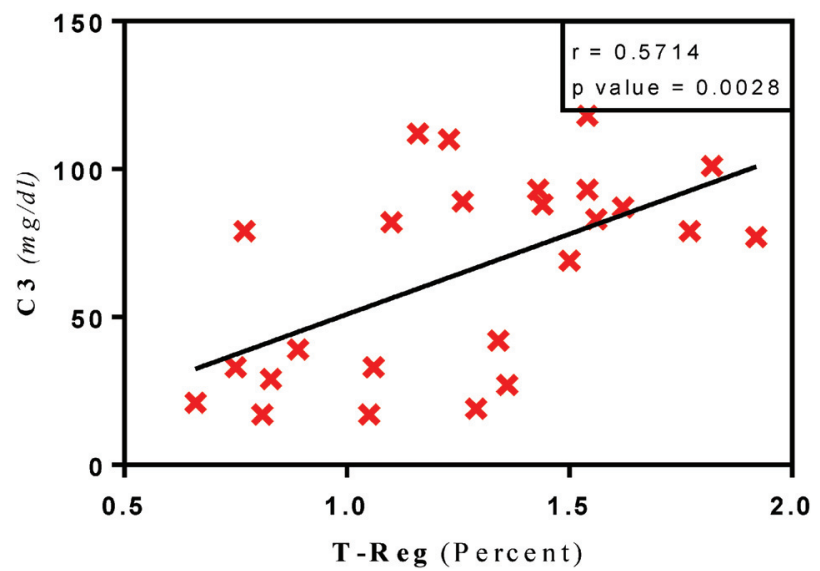

Show Positive correlations is observed between T-Reg (Percent) and C3 $(r=0.5714 \& P=0.0028)$ (Both are depleted).

Figure 5

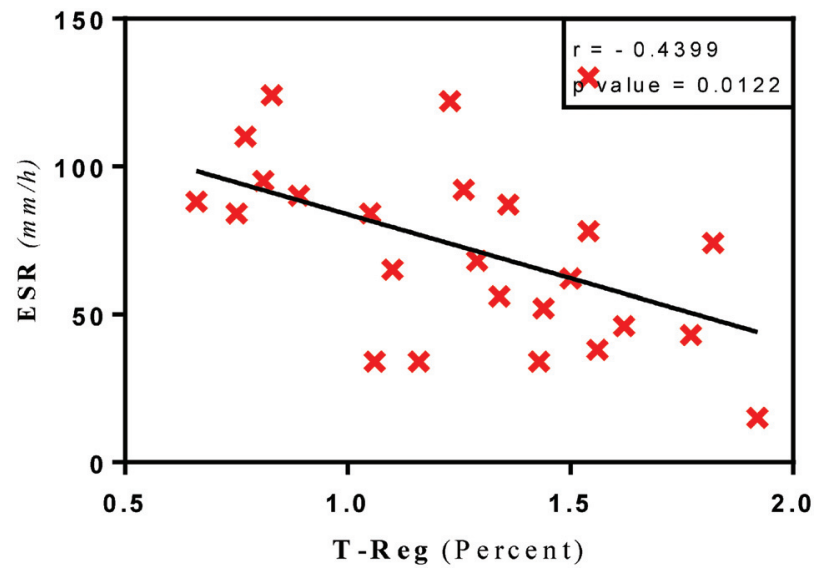

Show Negative correlations is observed between T-Reg (Percent) and ESR $(r=0.4399 \& P=0.0122)$.

and B-cell abnormalities have been described, and these include defects in Tregs that normally prevent pathologic self-reactivity $[25,26]$.

Iikuni and colleagues adds supportive evidence to this explanation, as they stated that in humans with SLE, the Treg can directly suppress autoantibody-producing B cells, including those that belong to pathogenic subtypes that are found expanded in active SLE. The cell-to-cell dependent mechanisms of suppression of autoreactive $B$ cells by Treg in SLE, that could represent an attempt to directly control humoral autoimmunity, involve the release of perforin and granzyme by activated Treg and the induction of apoptosis in these autoreactive $\mathrm{B}$ cells [27].

In an attempt to understand the role of Treg in pathogenesis of SLE, Scalapino and Daikh [28] stated that, in addition to the B cells, Treg also 
Figure 6

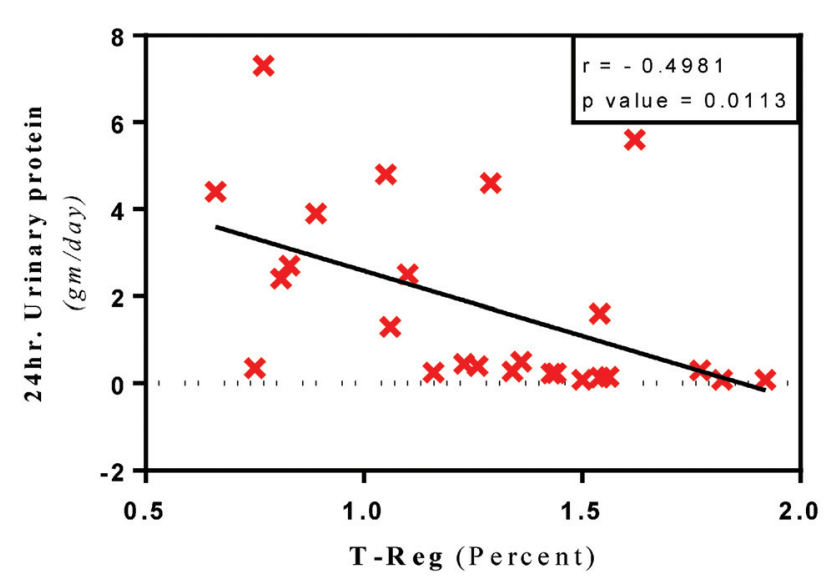

Show Negative correlations is observed between T-Reg (Percent) and $24 \mathrm{hr}$. Urinary protein $(r=-0.4981 \& P=0.0113)$.

Figure 8

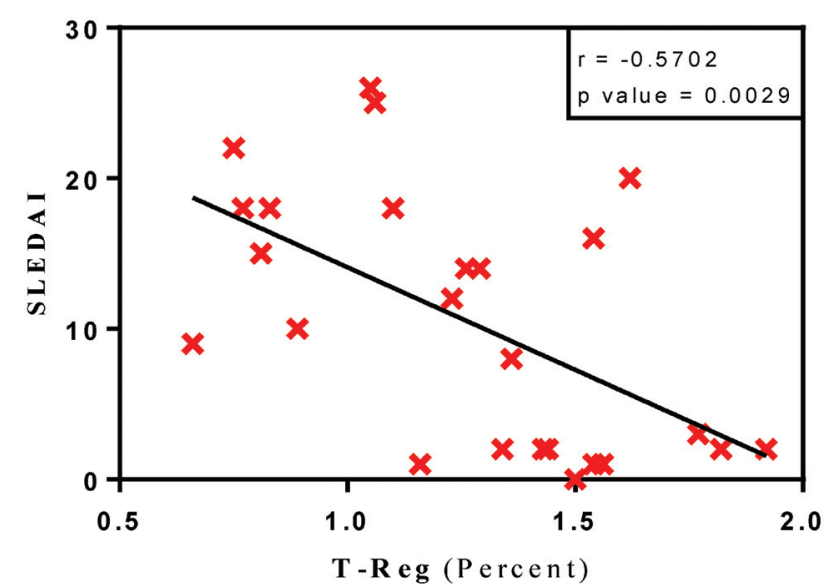

show Negative correlations is observed between T-Reg (Percent) and SLEDAI $(r=-0.5702 \& P=0.0029)$.

suppress lupus $\mathrm{CD}^{+} \mathrm{T}$ cells that provide help to autoantibody-producing $\mathrm{B}$ cells. This intermediate suppression of humoral immune responses by Treg in SLE involves the induction of a state of hyporesponsiveness to stimulation (anergy) in the $\mathrm{CD}^{+} \mathrm{T}$ helper cell (Th cell) and might represent a modality for the host to more effectively reduce the production of pathogenic autoantibodies, as both hyperactive Th cells and B cells would be rendered inactive by suppressor Treg.

Recently, it was suggested that autoimmunity in SLE may result when $\mathrm{CD}^{+} \mathrm{T}$ cell differentiation is biased away from Treg toward the Th17 cell phenotype. Szmyrka-Kaczmarek et al. [24] assessed Th17/Treg ratio in patients with SLE and found that the ratio of Th17 cells to Treg was markedly higher in patients with SLE than in the control group.
Figure 7

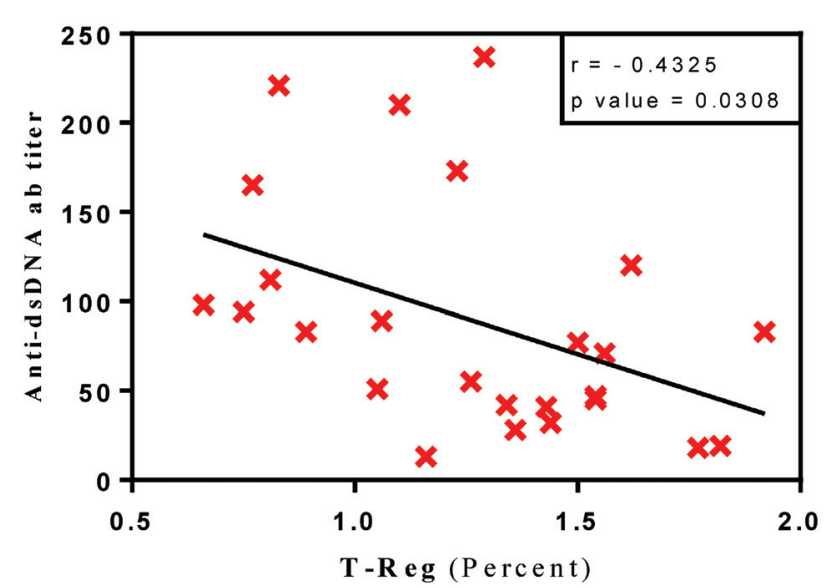

Show Negative correlations is observed between T-Reg (Percent) and Anti-dsDNAab ( $r=-0.4325$ \& $P=0.0308)$.

Figure 9

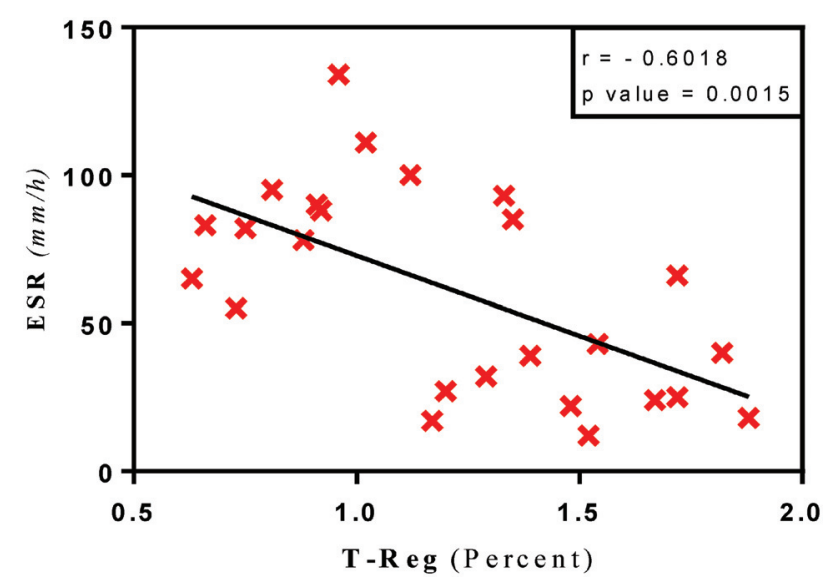

Negative correlation is observed between T-Reg (Percent) and DAS28 score $(r=-0.6825 \& P=0.0002)$.

Talaat and colleagues investigated the cytokines related to Tregs [transforming growth factor beta 1 (TGF$\beta 1$ )] and that related to Th17 (IL-17), and they found that patients with SLE have significantly higher levels of IL-17 but slight reduction of TGF- $\beta$ levels compared with controls. Moreover, this could imply skewing of T cells toward Th17 cells and breaking Th17/Treg balance [29].

Contrary to these finding, some studies report increased levels of Treg cells in SLE compared with those in healthy controls [30], or a resistance of lupus effector $\mathrm{T}$ cells to Treg cell suppression instead of defects of SLE Treg cells [31].

It is evident from the analysis of the different studies that the data arising from the evaluation of the global $\mathrm{CD}^{+} \mathrm{CD}^{2} 5^{+}$cell population are inconclusive, 
probably because of the extreme heterogeneity of this $\mathrm{T}$-cell subset. Indeed, as the percentage of circulating Treg in humans should be less than $2-3 \%$, the very high numbers and the wide variability of the reported percentages of the cell subpopulations considered in these studies, ranging from 6.5 to $31.3 \%$ in normal controls and from 6 to $37.8 \%$ in patients with SLE, appear to support this hypothesis [4].

Most of the earlier studies focused only on phenotypic characterization of circulating $\mathrm{T}$ cells, but they were limited by difficulties in distinguishing Treg cells from simply activated $\mathrm{T}$ cells bearing the CD25 surface molecule, as Treg cells in humans are more represented in $\mathrm{CD} 25^{\text {high }}$ cell fraction, which, however, is difficult to be unequivocally defined. It has been demonstrated, in fact, that the higher is CD25 surface expression the higher is suppressor activity. To more accurately discriminate between Treg and activated $\mathrm{T}$ cells, additional evaluations of FoxP3 mRNA expression within the $\mathrm{CD}^{+} \mathrm{CD}^{2} 5^{+}$cell population have been performed in some studies in patients with SLE. Recently, a more extensive analysis of FoxP3 expression has been possible with the availability of new tools for FoxP3 detection by flow cytometry that have improved data reliability [4].

Analysis of the results about FoxP3 cell expression in SLE is more complex, as the evaluation of its expression has been carried out with different methods and it has been analyzed within different cell subsets. However, it is of interest the observation that FoxP3 expression, when evaluated in both $\mathrm{CD} 25^{+}$and $\mathrm{CD} 25^{-}$cell subsets, seems to be reduced in the cell population bearing the CD25 and increased in the T-cell subset lacking this surface molecule [32]. Interestingly, similar results have been reported in a cohort of patients with new-onset SLE $[21,33]$.

Pathogenic basis of SLE may result also by an imbalance between effector and Tregs and not only by Treg cell impairment only. There is some evidence that impaired suppressor function is demonstrable when Treg are co-cultured with autologous effector $\mathrm{T}$ cells but not with effector $\mathrm{T}$ cells obtained from healthy donors, thereby suggesting a possible resistance of effector $T$ cells to Treg inhibition $[34,35]$. Moreover, these data, however, have not been confirmed in subsequent studies [36].

It is conceivable that many discrepancies about Treg findings in SLE may be dependent on both different phases of disease activity and immunosuppressive treatments that may affect viability and function of $\mathrm{T}$ cells. These findings are in agreement with the general observation that numerically decreased and/ or functionally defective Treg seem to be usually associated with active phases of the disease, whereas a phenotypic and functional picture similar to controls is the most frequent finding in inactive SLE $[20,33,37]$.

In the present study, there was a significant correlation between Treg percent and C3, C4 levels, ESR, and SLEDAI in patients with SLE. These results were discordant with Lee et al. [35], who found a nonsignificant correlation with either of $\mathrm{C} 3$ and $\mathrm{C} 4$ levels. However, they found a significant correlation with ESR levels.

Moreover, a significant negative correlation was found between Treg and anti-dsDNA antibody in patients with SLE, which is in agreement with $\mathrm{Ma}$ et al. [23], who found that the numbers of $\mathrm{CD} 4{ }^{+} \mathrm{CD} 25^{+} \mathrm{FoxP}^{+}$ in the anti-dsDNA ${ }^{+}$patients were significantly fewer than those in the anti-dsDNA ${ }^{-}$patients.

Our result showed a significant negative correlation between Treg and SLEDAI in patients with SLE, which is in agreement with $\mathrm{Ma}$ et al. [23].

Our results of decreased Treg cells percent in active SLE group compared with inactive group suggest an important role of these cells in pathogenesis of lupus activity. Moreover, a significant correlation of Treg with marker of disease activity is another evidence that can support this suggestion.

Our result of decrease Treg cells percent in RA compared with control group was in agreement with other groups [38-43].

The exact mechanisms that reduce the level of Tregs in RA are not clear. It was suggested that regulatory cells are recruited to sites of inflammation in an attempt to suppress disease, resulting in a relative reduction in the peripheral blood population [38].

Reports of a higher number of Tregs present in synovial fluid than that in the peripheral blood in patients with RA support this explanation. Tregs accumulated in inflamed joints express high levels of surface and intracellular CTLA-4, GITR, OX-40, and FoxP3 [44].

Moreover, Tregs were found to display increased tendency to undergo spontaneous apoptosis in active RA. Some studies [45-47] proposed that in an 
inflammatory condition like RA, it is quite possible that Tregs in the presence of the different proinflammatory cytokines will become unstable and convert to pathogenic $\mathrm{T}$ cells. This decline in Treg numbers may predispose to persistent autoimmune diseases including RA [38].

Recently, it was suggested that decreased level of Tregs in RA may be owing to transdifferentiation to Th17 cells [48].

Al-Zifzaf and colleagues who investigated the frequency of $\mathrm{FoxP}^{+} \mathrm{CD}^{+} \mathrm{CD} 25^{\text {thigh }}$ cells in 40 Egyptian patients with RA also studied TGF- $\beta$ : IL17 ratio to throw light on the imbalance between these two cytokines in RA. They found that the frequency of Tregs was significantly decreased among patients with RA compared with control $(2.37 \pm 0.73$ and 6.88 $\pm 7.26 \%$, respectively, $P=0.000$ ), and TGF- $\beta$ : IL-17 ratio was lower in patients with $\mathrm{RA}$ compared with controls [49].Similar results were found by Gaafar and colleagues who assessed the Treg/Th17 ratio and Th17-related cytokines, in peripheral blood of Egyptian patients with RA. They found that patients with active RA revealed an obvious increase in peripheral Th17 frequencies and levels of Th17related cytokines and a significant decrease in Treg $\left(\mathrm{CD}^{+} \mathrm{CD}^{2} 5^{+} \mathrm{FoxP}^{+}\right)$frequencies when compared with healthy controls [50].

Contrary to our results, there are reports of increased Tregs in peripheral blood of patients with RA [51,52], but in these research studies, the authors assessed different $\mathrm{CD}^{+} \mathrm{CD} 25^{+} \mathrm{T}$ cell subtypes (including $\mathrm{CD}^{+}{ }^{+} \mathrm{T}$-cells expressing low levels of CD25 and those expressing FoxP3 and those not expressing it), which could account for the discrepancy in the results.

We found a significant negative correlation between DAS-28 score and the decrease in frequency of Treg. The lower the frequency of Tregs, the higher the DAS28 score reflecting higher disease activity, and also ESR and CRP. This may indicate the importance of Treg cells in pathogenesis of RA activity, but the precise role of their deficiency in pathogenesis of activity needs to be defined by further studies. Others did not report any correlation between Treg frequencies or cytokines with DAS-28 score $[43,49]$.

\section{Conclusion}

$\mathrm{CD} 4^{+} \mathrm{CD} 25^{+}$FoxP3 Tregs percentage of CD4 cells was significantly lower in patients with SLE and those with RA when compared with healthy controls.
Moreover, patients with active SLE and those with RA showed significantly lower Treg cells percent than inactive groups, and $\mathrm{CD}^{+} \mathrm{CD} 25^{+}$FoxP3 Tregs percentage of $\mathrm{CD} 4$ cells was significantly correlated with ESR, C3, C4 levels, and SLEDAI score in patients with SLE. Moreover, it was significantly correlated with ESR, CRP, and DAS-28 score in patients with RA, which is the main marker of disease activity, indicating a power to detect patients with active disease.

\section{Acknowledgements}

The authors thank members of the laboratory in $\mathrm{Al}$ Hussein University Hospital for the aid in preparation of this manuscript.

\section{Financial support and sponsorship} Nil.

\section{Conflicts of interest}

There are no conflicts of interest.

\section{References}

1 Szmyrka-Kaczmarek M, Kosmaczewska A, Ciszak L, Szteblich A, Wiland $P$. Peripheral blood Th17/Treg imbalance in patients with low-active systemic lupus erythematosus. Postepy Hig Med Dosw 2014; 68:893-898.

2 Horwitz DA. Identity of mysterious CD4+CD25-Foxp3+ cells in SLE. Arthritis Res Ther 2010; 12:101.

3 Adlan AM, Lip GY, Paton JF, Kitas GD, Fisher JP. Autonomic function and rheumatoid arthritis: a systematic review. Semin Arthritis Rheum 2014; 44:283-304.

4 Gerli R, Nocentini G, Alunno A, Bocci EB, Bianchini R, Bistoni O, et al. Identification of regulatory $T$ cells in systemic lupus erythematosus. Autoimmun Rev 2009; 8:426-430.

5 Sakaguchi S, Sakaguchi N, Asano M, Itoh M, Toda M. Immunologic selftolerance maintained by activated $T$ cells expressing IL-2 receptor alphachains (CD25). Breakdown of a single mechanism of self-tolerance causes various autoimmune diseases. J Immunol 1995; 155:1151-1164.

6 Chang $X$, Zheng P, Liu Y. FoxP3: a genetic link between immunodeficiency and autoimmune diseases. Autoimmun Rev 2006; 5:399-402.

7 Banham AH. Cell-surface IL-7 receptor expression facilitates the purification of FOXP3(+) regulatory $T$ cells. Trends Immunol 2006; 27:541-544.

8 Wang T, Sun X, Zhao J, Zhang J, Zhu H, Li C, et al. Regulatory T cells in rheumatoid arthritis showed increased plasticity toward Th17 but retained suppressive function in peripheral blood. Ann Rheum Dis 2015; 74:1293-1301.

9 Kleczynska W, Jakiela B, Plutecka H, Milewski M, Sanak M, Musial J. Imbalance between Th17 and regulatory T-cells in systemic lupus erythematosus. Folia Histochem Cytobiol 2011; 49:646-653.

10 Petri M, Orbai AM, Alarcón GS, Gordon C, Merrill JT, Fortin PR, et al. Derivation and validation of the Systemic Lupus International Collaborating Clinics classification criteria for systemic lupus erythematosus. Arthritis Rheum 2012; 64:2677-2686.

11 Aletaha D, Neogi T, Silman AJ, Funovits J, Felson DT, Bingham CO, et al. 2010 rheumatoid arthritis classification criteria: an American College of Rheumatology/European League against rheumatism collaborative initiative. Ann Rheum Dis 2010; 69:1580-1588.

12 Prism 20157 for Windows runs under either the 32- or 64-bit versions of Windows Vista, 7,8 or 10. Prism will run in a screen as small as $800 \times 540$. While it runs fine on 64 bit versions of Windows, it is a 32 bit program.

13 Leung N, Mabarrack N, Barbour A, Cummins A, Barry S. Foxp3+ regulatory T cells, Th17 effector cells, and cytokine environment in inflammatory bowel disease. J Clin Immunol 2010; 30:80-89. 
14 William J, Timothy B, Dirk E. Andrews' diseases of the skin: clinical dermatology. ISBN 0-7216-2921-0. (10th ed.). USA: Saunders; 2005.

15 Jacobi AM, Diamond B. Balancing diversity and tolerance: lessons from patients with systemic lupus erythematosus. J Exp Med 2005; 202:341-344

16 Horwiz DA. Regulatory T cells in systemic lupus erythematosus:past, present and future. Arthritis Res Ther 2008; 10:227.

17 Cooles FA, Isaacs JD, Anderson AE. Treg cells in rheumatoid arthritis: an update. Curr Rheumatol Rep 2013; 15:352.

18 Miyara M, Amoura Z, Parizot C, Badoual C, Dorgham K, Trad S, et al. Global natural regulatory $T$ cell depletion in active systemic lupus erythematosus. J Immunol 2005; 175:8392-8400.

19 Lyssuk EY, Torgashina AV, Soloviev SK, Nassonov EL, Bykovskaia SN. Reduced number and function of CD4+CD25highFoxP3+ regulatory T cells in patients with systemic lupus erythematosus. Adv Exp Med Biol 2007; 601:113-119.

20 Valencia X, Yarboro C, Illei G, Lipsky PE. Deficient CD4+CD25high T regulatory cell function in patients with active systemic lupus erythematosus. J Immunol 2007; 4:2579-2588.

21 Bonelli M, Savitskaya A, von Dalwigk K, Steiner CW, Aletaha D, Smolen JS, Scheinecker C. Quantitative and qualitative deficiencies of regulatory T cells in patients with systemic lupus erythematosus (SLE). Int Immunol 2008; 20:861-868.

22 Xing Q, Wang B, Su H, Cui J, Li J. Elevated Th17 cells are accompanied by FoxP3+ Treg cells decrease in patients with lupus nephritis. Rheumatol Int 2012; 32:949-958.

23 Ma L, Zhao P, Jiang Z, Shan Y, Jiang Y. Imbalance of different types of CD4 +forkhead box protein 3 (FoxP3)+ T cells in patients with new-onse systemic lupus erythematosus. Clin Exp Immunol 2013; 174:345-355.

24 Szmyrka-Kaczmarek M, Kosmaczewska A, Ciszak L, Szteblich A, Wiland P. Peripheral blood Th17/Treg imbalance in patients with low-active systemic lupus erythematosus. Postepy Hig Med Dosw (Online) 2014; 68:893-898.

25 Liu MF, Wang CR, Fung LL, Wu CR. Decreased CD4+CD25+ T cells inperipheral blood of patients with systemic lupus erythematosus. Scand $J$ Immunol 2004; 59:198-202.

26 Yang $X Y$, Lu XY, Xu DH, Lu QH, Wang QH, Wu HX. Clinical significance of CD4+CD25+ $T$ cells in peripheral blood of patients in systemic lupus erythematosus. Zhonghua Nei Ke Za Zhi 2005; 44:570-572.

27 likuni N, Lourenço EV, Hahn BH, La Cava A. Cutting edge: regulatory T cells directly suppress $B$ cells in systemic lupus erythematosus. J Immunol 2009; 183:1518-1522.

28 Scalapino KJ, Daikh DI. Suppression of glomerulonephritis in NZB/NZW lupus-prone mice by adoptive transfer of ex vivo expanded regulatory $T$ cells. PLoS One 2009; 4:e6031.

29 Talaat RM, Mohamed SF, Bassyouni IH, Raouf AA. Th1/Th2/Th17/Treg cytokine imbalance in systemic lupus erythematosus (SLE) patients: correlation with disease activity. Cytokine 2015; 72;146-153.

30 Lin S, Chen K, Lin C, Kuo CC, Ling QD, Chan CH. The quantitative analysis of peripheral blood FOXP3- expressing T cells in systemic lupus erythematosus and rheumatoid arthritis patients. Eur J Clin Invest 2007; 37:987-996.

31 Venigalla RK, Tretter T, Krienke S, Max R, Eckstein V, Blank N, et al. Reduced CD4+, CD25- T cell sensitivity to the suppressive function of CD4 +,CD25high,CD127 -/low regulatory T cells in patients with active systemic lupus erythematosus. Arthritis Rheum 2008; 58:2120-2130.

32 Zhang B, Zhang X, Tang F, Zhu L, Liu Y. Reduction of forkhead box P3levels in CD4+CD25 high T cells in patients with new onset systemic lupus erythematosus. Clin Exp Immunol 2008; 153:182-187.

33 Cepika AM, Marinic I, Morovic-Vergles J, Soldo-Juresa D, Gagro A. Effect of steroids on the frequency of regulatory Tcells and expression of FOXP3 in a patient with systemic lupus erythematosus: a two year follow-up. Lupus 2007; 16:374-377.

34 Mellor-Pita S, Citores MJ, Castejon R, Tutor-Ureta P, Yebra-Bango M, Andreu JL, et al. Decrease of regulatory T cells in patients with systemic lupus erythematosus. Ann Rheum Dis 2006; 65:553-554.
35 Lee HY, Hong YK, Yun HJ, Kim YM, Kim JR, Yoo WH. Altered frequency and migration capacity of $\mathrm{CD} 4+\mathrm{CD} 25+$ regulatory $\mathrm{T}$ cells in systemic lupus erythematosus. Rheumatology (Oxford) 2008; 47:789-794.

36 Vargas-Rojas MI, Crispín JC, Richaud-Patin Y, Alcocer-Varela J. Quantitative and qualitative normal regulatory $\mathrm{T}$ cells are not capable of inducing suppression in SLE patients due to T-cell resistance. Lupus 2008; 17:289-294.

37 Yates J, Whittington A, Mitchell P, Lechler RI, Lightstone L, Lombardi G. Natural regulatory Tcells: number and function are normal in themajority of patients with lupus nephritis Clin Exp Immunol 2008; 153:44-55.

38 Lawson CA, Brown AK, Bejarano V, Douglas SH, Burgoyne CH, Greenstein AS, et al. Early rheumatoid arthritis is associated with a de cit in the CD4 + CD25high regulatory $T$ cell population in peripheral blood. Rheumatology (Oxford) 2006; 45:1210-1217.

39 Sempere-Ortells JM, Pérez-Garcia V, Marin-Alberca G, Peris-Pertusa A Benito JM, Marco FM, et al. Quanti cation and phenotype of regulatory T cells in rheumatoid arthritis according to disease activity score-28. Autoimmunity 2009; 42:636-645.

40 Samson M, Audia S, Janikashvili N, Ciudad M, Trad M, Fraszczak J, et al. Brief report: inhibition of interleukin-6 function corrects Th17/Treg cell imbalance in patients with rheumatoid arthritis. Arthritis Rheum 2012; 64:2499-2503.

41 Chen R, Tao Y, Qiu K, Huang W, Huang C, Li J. Association of circulating Treg cells with disease activity in patients with rheumatoid arthritis. Nan Fang Yi Ke Da Xue Xue Bao 2012; 32:886-889.

42 Moradi B, Schnatzer P, Hagmann S, Rosshirt N, Gotterbarm T, Kretzer JP, et al. CD4+ CD25+/high CD127 low/- regulatory T cells are enriched in rheumatoid arthritis and osteoarthritis joints-analysis of frequency and phenotype in synovial membrane, synovial fluid and peripheral blood. Arthritis Res Ther 2014; 16:97.

43 Zare H-R, Habibagahi M, Vahdati A, Habibagahi Z. Patients with active rheumatoid arthritis have lower frequency of ntregs in peripheral blood. Iran $\mathrm{J}$ Immunol 2015; 12:166-175.

44 Mottonen M, Heikkinen J, Mustonen L, Isomäki P, Luukkainen R, Lassila O. CD4pCD25p T cells with the phenotypic and functional characteristics of regulatory $T$ cells are enriched in the synovial fluid of patients with rheumatoid arthritis. Clin Exp Immunol 2005; 140:360-367.

45 Toubi E, Kessel A, Mahmudov Z, Hallas K, Rozenbaum M, Rosner I. Increased spontaneous apoptosis of CD4+CD25+ $T$ cells in patients with active rheumatoid arthritis is reduced by infliximab. Ann N Y Acad Sci 2005; 1051:506-514.

46 Li N, Ma T, Han J, Zhou J, Wang J, Zhang J, et al. Increased apoptosis induction in CD4+ CD25+ Foxp3+ T cells contributes to enhanced disease activity in patients with rheumatoid arthritis through IL-10 regulation. Eur Rev Med Pharmacol Sci 2014; 18:78-85.

47 Chavele K, Ehrenstein M. Regulatory T-cells in systemic lupus erythematosus and rheumatoid arthritis FEBS Lett 2011; 585:3603-3610.

48 Komatsu N, Okamoto K, Sawa S, Nakashima T, Oh-hora M, Kodama T, et al. Pathogenic conversion of Foxp3+ T cells into TH17 cells in autoimmune arthritis. Nat Med 2014; 20:62-68.

49 Al-Zifzaf D, El Bakry S, Mamdouh R, Shawarbyc L, Abdel A, Amer HA, et al. FoxP3+T regulatory cells in Rheumatoid arthritis and the imbalance of the of the Treg/TH17 cytokine axis. Egypt Rheumatol 2015; 37:7-15.

50 Gaafar T, Farid R, Raafat H, Bayoumi F, Gerges B, Rasheed D. The TH17/ Treg imbalance in rheumatoid arthritis and relation to disease activity. $\mathrm{J}$ Clin Cell Immunol 2015; 6:1-7. DOI: 10.4172/2155-9899.1000381

51 van Amelsfort JM, Jacobs KM, Bijlsma JW, Lafeber FP, Taams LS. CD4(p) CD25(b) regulatory $T$ cells in rheumatoid arthritis: differences in the presence, phenotype, and function between peripheral blood and synovial fluid. Arthritis Rheum 2004; 50:2775-2785.

52 Han GM, O'Neil-Andersen NJ, Zurier RB, Lawrence DA. CD4+CD25high T cell numbers are enriched in the peripheral blood of patients with rheumatoid arthritis. Cell Immunol 2008; 253:92-101. 